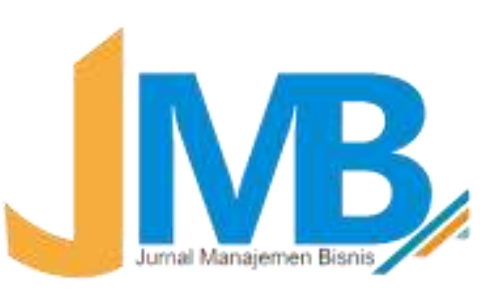

\title{
Analysis of Behavior Using E-money With A TAM Approach (Technology Acceptance Model)
} Indah Retno Wulandari ${ }^{1}$, Sumadi ${ }^{2}$

Islamic Univercity of Indonesia, Yogyakarta, Indonesia ${ }^{1,2}$

Corresponding Author's Email: indahrw52@gmail.com

Received:08-01-2020| Revision: 28-06-2020| Accepted:11-07-2020

To cite this document:

Wulandari, Indah Retno and Sumadi, (2020) "Analysis of Behavior Using E-money With A TAM Approach (Technology Acceptance Model)", Manajemen Bisnis, Vol. $10 \quad$ No.1, pp.24-32, http://ejournal.umm.ac.id/index.php/jmb/article/view/10861

\begin{abstract}
E-money is a non-cash electronic payment instrument that is currently growing rapidly in Indonesia. Based on Bank Indonesia data, there are already 39 banking and non-bank companies that have obtained permits to issue e-money products. This study aims to determine and analyze perceptions of the benefits of attitudes, perceptions of ease of attitudes, levels of trust in interests, attitudes affect interests, and interests influence behavior using E-Money.The population in this study were all e-money users in the Java Island region. Samples taken in this study are some e-money users in the Java Island region, amounting to 200 respondents. Sampling using non-probability techniques with convenience sampling method and research models were analyzed using Structural Equation Model (SEM), using the help of AMOS software.The results of this study indicate that the perception of benefits has a significant positive effect on attitude, the perception of ease has a significant positive effect on attitude, the level of trust has a significant positive effect on interest, attitude has a significant positive effect on interest and interest has a significant positive effect on behavior using e-money.
\end{abstract}

Keywords: perceived usefulness, perceived ease of use, level of trust, attitude, interest, behavior

\section{INTRODUCTION}

In the current era of globalization, technology is developing rapidly so as to encourage intense business competition. Every company must be able to determine the right strategy and innovation in order to survive in business competition. So, companies must create innovations and creative ideas to meet the needs of the community and create customer satisfaction. Information Technology (IT) has been widely used by companies to do business. Information Technology helps to make decisions from company management to increase competition in the market (Teak, 2012). Information Technology provides benefits to meet information needs quickly, timely and relevant. It has been proven that the form of payment which was originally cash (cash) has now shifted to non-cash (cashless). 
E-money is a micro-payment tool whose characteristics are considered the most feasible to be maximized, in the form of stored used facilities. The emergence of electronic money is to meet the needs of the people who are expected to make payments quickly and costs that tend to be relatively cheaper. The purpose of electronic money is to be able to make payments quickly and easily in every transaction without carrying cash. The benefit for the owner of the e-money card is that by using e-money the card owner no longer gets change either change or candy. Using e-money also increases high efficiency.

The use of e-money continued to increase from 2007 to 2019. Currently in July the amount of electronic money in circulation was $232,348,971$ (bi.go.id). This is due to competition from e-money issuing banks and strategies to look after their customers. Even banks issue many electronic money payments. Non-financial organizations such as gojek issue gopaye-money and then followed by other non-bank institutions such as Telkomsel. There are 39 institutions entitled to issue electronic money payments in 2019 , according to BI. The significant development of emoney in Indonesia is an interesting thing to study. Therefore, the authors are interested in knowing about customer behavior to electronic money. Consumers behave in the use of electronic money allegedly there are several factors that cause. Engel et.al (2006) Consumer behavior is the activity of a person who is immediately involved in a service, which includes implementation for decision making.

\section{LITERATURE REVIEW}

TAM theory is used to predict the adoption of the use of IT applications in organizations, many researchers have modified the original model to explain many needs (Keat and Mohan, 2004: 404). Davis continues to develop the TAM model to see computer technology user acceptance where the use of technology is determined by behavioral interest, where the behavioral interest itself is determined by attitudes toward behavior and perceived usefulness (Davis, Bagozzi and Warshaw, 1989: 982). In TAM theory, perception of benefits and perception of ease will influence attitudes towards the use of technology. Increased perceptions of convenience will affect the increase in perceived benefits because an easy-to-use system does not require a long time to be studied so that individuals have the opportunity to do something else so that it is related to the effectiveness of performance (Davis, Bagozzi and Warshaw, 1989). The attitude in TAM is conceptualized as an attitude towards the use of a system in the form of acceptance or rejection as an impact if someone uses a technology in his work. Interest is the tendency of behavior to keep using a technology.

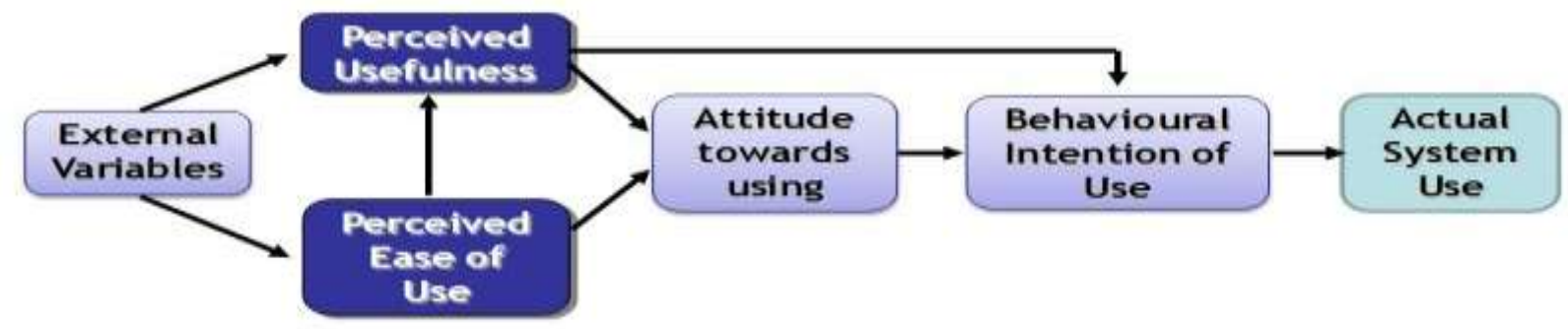

Figure 1. Technology Acceptance Model (TAM) Davis, Bagozzi and Warshaw in Cahyo (2014) 
Perceived usefulness as a belief in usefulness, which is the degree to which users believe that the use of technology or systems will improve their performance in work (Davis, 1989). Thompson et. al. (1991) also mentioned that individuals will use information technology if they know the positive benefits of its use. Davis (1989) uses the term Percieved ease of use, which is used to assess a person's ease of using technology and the concept or TAM approach. Perceived convenience is where someone believes that using the technology is easy to use. Trust is a person's awareness of an action of another party where that party is carrying out certain measures against the individual. Trust is one's awareness to take risks, not to take risks (Mayer et.al, 1995). Many factors can form trust.

Based on Schiffman \& Kanuk, (2010) defines attitude is a predisposition of positions learned in responding to always an object, a form of liking / disliking. There are several sources that influence attitudes such as Schiffman and Kanuk (2010) which is influence of family and peer group (the family has an influence on buying interest. Many studies have shown that peers with games can influence buying behavior) and experience (repurchase intention will be influenced by the use of the product / service at the last time). Interest according to Fishbein and Ajzen (1975), is a component in individuals that refers to the desire to perform certain behaviors. intention is defined as an individual's subjective probability dimension in relation to self and behavior. Consumer behavior is a depiction of a person's behavior in choosing, paying, implementing, valuing, and ending the consumption of goods / services and ideas (Schiffman \& Kanuk, 2010).

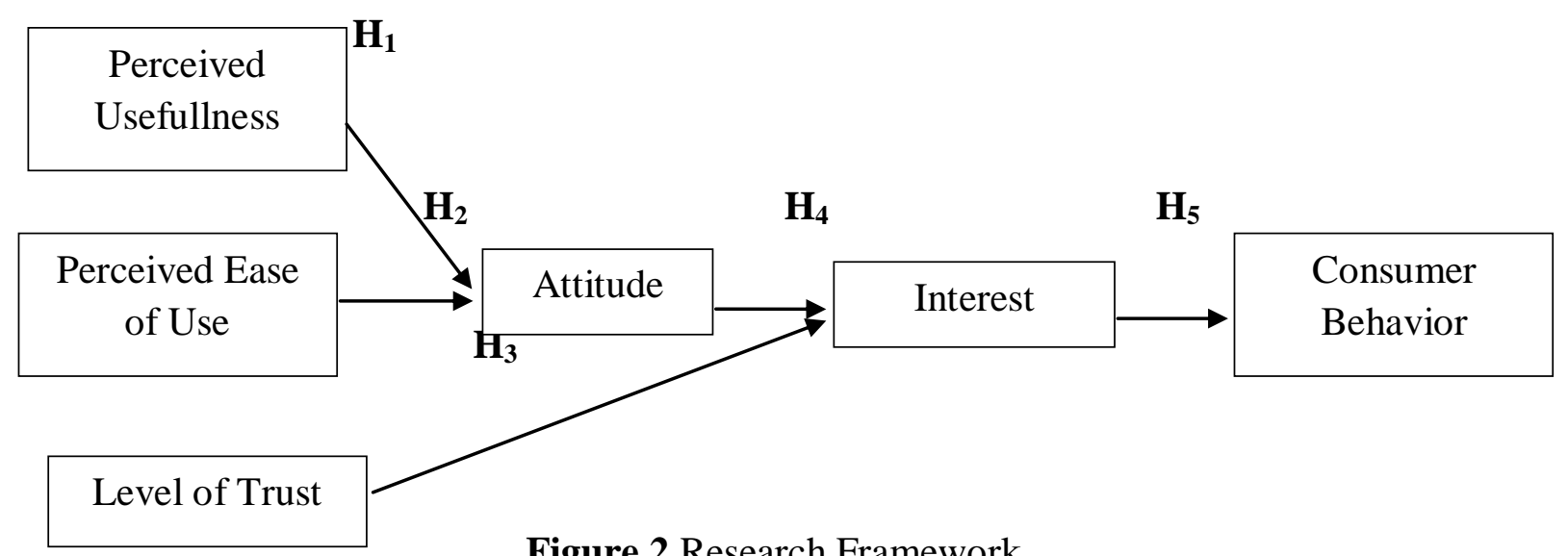

Figure 2 Research Framework

\section{RESEARCH METHOD}

The research conducted was quantitative primary research. The research location is Java Island. The population of this study is all people who have used e-money in the Java Island region. The choice of the Java Island is based on diversity and is very dynamic, and is responsive and sensitive to change. The sample of this research is the majority of people who have used emoney in the Java Island region. The sampling used is non-probability techniques with convenience sampling method that is sampling based on convenience. The number of samples of 
this study were 200 respondents. Data collection for this study was a questionnaire. How to collect data using Google forms that are distributed through various social media platforms. With the data testing process using SEM AMOS 20.

\section{RESULT AND DISCUSSION}

\section{Structural Equation Model}

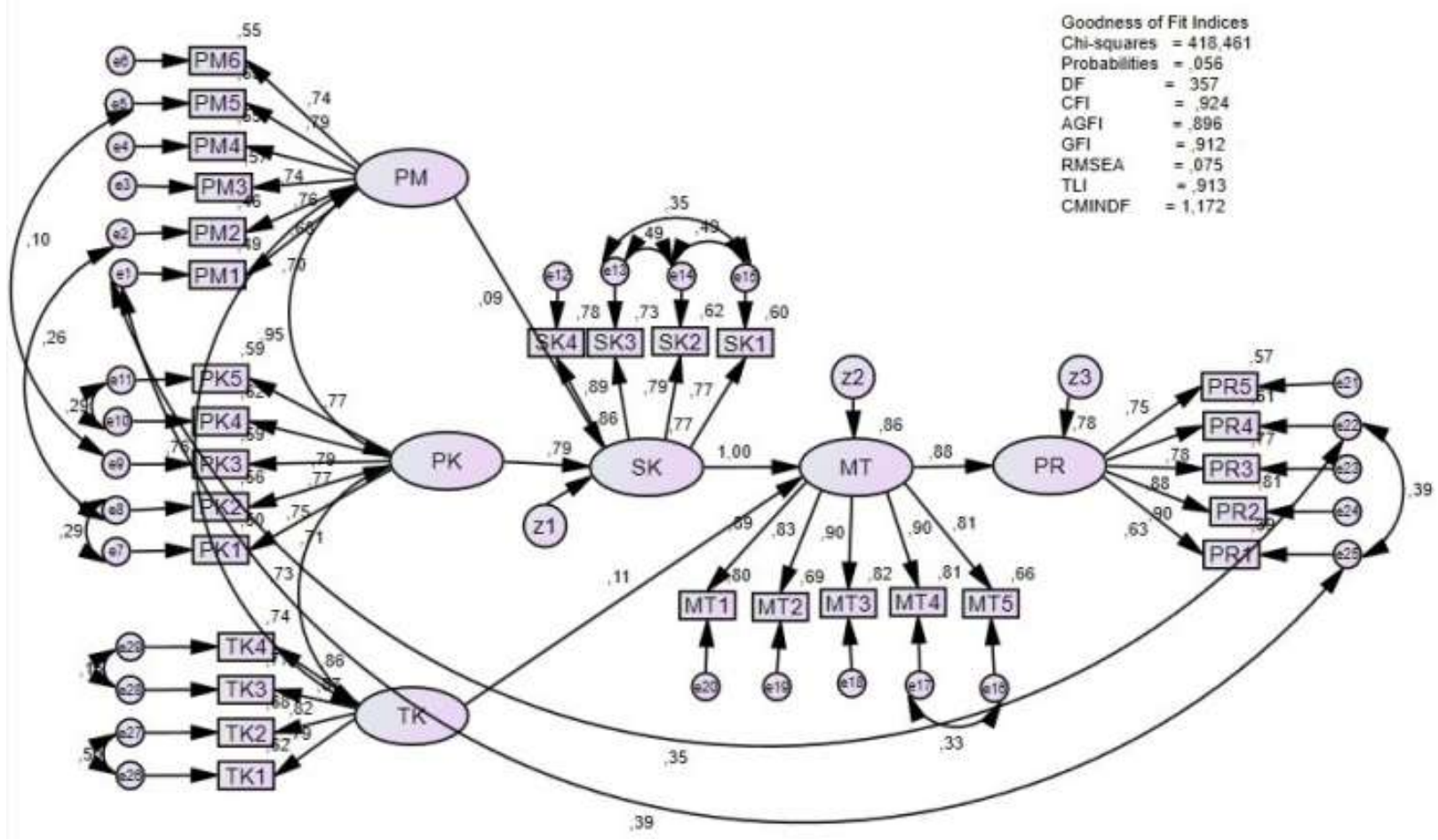

Figure 3 Structural Equation Model Result

Table 1 Correlation Between Variables

\begin{tabular}{cccccc}
\hline $\begin{array}{c}\text { Correlation between } \\
\text { variables }\end{array}$ & Standardized & S.E. & C.R. & P & Lable \\
\hline SK $\leftarrow$ PM & 0,094 & 0,391 & 4,937 & 0,043 & Par_26 \\
\hline SK $\leftarrow$ PK & 0,790 & 0,343 & 2,648 & 0,000 & Par_22 \\
\hline MT $\leftarrow$ TK & 0,112 & 0,072 & 2,029 & 0,044 & Par_25 \\
\hline MT $\leftarrow$ SK & 0,997 & 0,098 & 10,539 & 0,000 & Par_23 \\
\hline PR $\leftarrow$ MT & 0,881 & 0,084 & 10,793 & 0,000 & Par_24 \\
\hline
\end{tabular}

The results of this study prove that the perception of benefits has a positive and significant effect on attitudes using e-money. The more benefits in using e-money, it will improve one's attitude to use it. One's intention refers to the anticipated or planned future attitude. Davis (1989) defines perceived usefulness as the extent to which a person believes that 
the use of a technology will improve his work performance. To be used, a system must be able to provide benefits and value for the users of the system itself. To be able to influence attitudes, emoney companies must be able to provide benefits to its users. If E-money can improve the performance of its users and provide benefits and value for its users, then the consumer will use the payment instrument. Based on the explanation, the intended benefit is that e-money must be able to improve performance, effectiveness, productivity, and usefulness for its users. If an emoney company is able to provide benefits to its users, then e-money users will also give a good response. These results are in accordance with research (Bangkara \& Mimba, 2016) proving that perceived usefulness has a positive effect on attitude toward using internet banking. These results are also supported by research Sidharta\&Sidh (2014) states that perceived usefulness has a significant and significant influence on students' attitudes to make online purchases in ecommerce.

Hypotheses 2 prove that perceptions of ease have a positive and significant influence on attitudes using e-money. The more convenience in using E-money, it will improve one's attitude to use it. Venkatesh and Davis (2000) point out that convenience is an important factor in making payments. In this study the ease in question is the ease of using e-money. Ease of use is one of the factors that can influence consumer attitudes in making payments. If consumers think that using e-money is an easy thing, it will also make it easier for consumers to make transactions. This result is in line with Bangkara and Mimba (2016) research which proves that Perceived Ease of Use has a positive effect on attitude toward using internet banking. These results are also supported by research by Juhri\&Dewi (2017) which states that perceived ease of use influences attitude toward using mobile money T-cash in Bandung.

The results of hypotheses 3 prove that the level of trust has a positive influence on interest in using e-money. The higher the level of trust will increase interest in using e-money. It can be analyzed that consumers in Indonesia tend to be motivated to use e-money if they consider e-money as a technology that can be trusted both in terms of safety and comfort. On the other hand, trust also shapes consumer perceptions of e-money as a new technology that can maintain the security of consumer transactions. This indirectly forms the level of consumer confidence in the quality of e-money so that consumers are interested in using e-money. In addition, consumers trust information provided by e-money service providers such as information about the remaining e-money balance. or transaction results. These reasons are driving consumers to increase interest in using e-money. In this study, consumer confidence is proven to be one important factor in the interest in using e-money. So that these results can be a basis for input for companies providing e-money services both banking and non-banking. Every company must improve the quality and performance in providing e-money services. Revamping the policies and regulations on the use of e-money can be improved again related to consumer safety in making transactions using e-money. For example, an e-money service provider company must be able to provide responsibility if consumers experience problems in dealing with e-money. Then the company can also provide positive testimonial evidence of the use of emoney so that it can increase consumer confidence in e-money. These results are in accordance 
with research conducted by Romadloniyah and Prayitno (2018), Ultimate (2018), Widodo et al (2015), Pratama and Suputra (2019) which show that trust influences the interests of e-money users.

The results of hypotheses 4 prove that attitude has a positive and significant effect on interest in using e-money. The higher attitude will increase interest in using e-money. Davis, (1989); Davis et al., (1989) defines the attitude of behavior as positive or negative feelings from someone if they should carry out the behavior to be determined. Interest in behavior itself is a function of the attitude of individual behavior. If it is associated with the intention to use emoney, one's attitude will increase the use of e-money. According to such a thing it can be said that one's attitude to the info method shows how far people enjoy that the method is good or bad for themselves. These results are in accordance with the research of Khatimah\& Halim, (2016a), Khatimah\& Halim, (2016b) and Sumerta\&Wardana, (2018) prove that attitudes have a positive effect on the use of e-money. The research was strengthened by research conducted by LiébanaCabanillas, de Luna, \& Montoro-Ríosa, (2017), Ting, Yacob, Liew, \& Lau, (2016), and Teng, Ling, \& Seng (2018) prove that attitude is influential positive about the interest in using mobile payments.

The results of hypotheses 5 prove that interest has a positive and significant influence on behavior using e-money. The higher interest will increase behavior using e-money.Consumers 'attitudes to e-money affect purchasing interest where relevant attitude changes are changing consumers' attitudes towards brands without changing their trust so that it impacts the community as consumers of products / services. Purchase interest refers to the extent of attitude with feelings in the future and associates attitude with feelings and beliefs themselves. Behavior intention is an act of someone in a method in the future that will compile a person's specific behavior (Mcknight et al., 2002). The intention to behave as someone's intention to carry out certain actions that can predict one's behavior when doing voluntary (Islam, Low, \& Hasan, 2013). Thus, the intention to show the element of enthusiasm that influences behavior and how individuals try to engage in behavior and build individual decisions according to thought whether the individual will carry out a behavior or not behave (Alasmari, 2018). These results are in accordance with research by Seetharaman, Kumar, Palaniappan, \& Weber (2017) proving that interest in using a mobile wallet has a positive effect on the behavior of using a mobile wallet in Singapore.These results are also supported by research by Sunny \& George (2018) and Anthony \& Mutalemwa (2014) who found the results of interest affect mobile paying behavior.

\section{CONCLUSION}

This study can be concluded that perception of benefits and a significant positive effect on the attitude of using E-money. Perception Ease has a positive and significant effect on the attitude of using E-money, which means that the more ease in using e-money, it will improve one's attitude to use it. The level of trust has a positive and significant effect on the interest in using emoney, which means that the higher the level of trust will increase interest in using e-money. Attitude has a significant positive effect on interest in using e-money. Interest has a positive and significant effect on behavior using e-money, which means the higher interest will increase the 
behavior of using e-money. It can be concluded that consumer behavior in using e-money is influenced by interest. Someone's interest in using E-money is also influenced by attitude. While consumers' attitudes to use e-money are influenced by perceptions of benefits, perceptions of ease and level of trust of e-money products used

\section{REFERENCES}

Alasmari, T. M. (2018). Mobile Learning Technology Acceptance Among Saudi Higher Education Students. PhD Dissertation. Wayne State University

Bangkara, R.P. dan Mimba N.P (2016). Pengaruh Perceived usefulness dan Perceived Ease Of Use Pada Minat Penggunaan Internet Banking Dengan Attitude Toward Using Sebagai Variable Intervening. E-Jurnal Akuntansi Universitas Udayana. Vol.16.3

Davis, F.D, Bagozzi danWarshaw. (1989). User Acceptance of ComputerTechnology: A Comparison of Two Theoritical Models. Journal of Management Science Vol. 35

Davis, F.D. (1989). Perceived Usefulness, Perceived Ease of Use, and User Acceptance of Technology. Journal of MIS Quarterly.

Dhulla, T.V., and Mathur, S.K. (2014), Adoption of Cloud Computing by Tertiary Level Students-A Study.Journal of Exclusive Management Science, 3 (3).

Engel et.al. (2006). Consumer Behaviour. Mason: Permissions. Department, Thomson Business and Economics.

Fishbein, M., \& Ajzen, I. (1975). Belief, Attitude, Behaviour: Belief, Attitude, Intention and Behavior: An Introduction to Theory and Research. California: Addison Wesley.

Gefen,et.al (2003),.Trust \& TAM in online shopping: an integrated model", MIS Quarterly (27:1),52-90

Harsono, L. D., dan Suryana L. A., (2014). Factors Affecting the Use Behavior of Social Media Using UTAUT 2 Model, Article presented in Proceedings of the First Asia-Pacific Conference on Global Business, Economics, Finance and Social Sciences (AP14Singapore Conference), Singapore.

Islam, M. Z., Low, P. K. C., \& Hasan, I. (2013). Intention to use advanced mobile phone services (AMPS). Management Decision, 824-838. https://doi.org/10.1108/00251741311326590

Jati, N. J. (2012). Analisis Faktor-Faktor yang Mempengaruhi Minat Pemanfaatan dan Penggunaan Sistem E-Ticket (Studi Empiris pada Biro Perjalanan di Kota Semarang). Diponegoro Journal of Accounting.

Juhri, K., Dewi,C.K .(2017). Kepercayaan Dan Penerimaan Layanan Mobile Banking T-Cash Di Bandung Dengan Pendekatan Technology Acceptance Model (TAM), Jurnal Pro Bisnis Vol. 10 No 1

Keat, dan Mohan. (2004). Integration of TAM Based Electronic Commerce Modelsfor Trust. Journal of America Academy of Business.pp 404 
Khatimah, H., \& Halim, F. (2016a). The effect of attitude and its decomposed, perceived behavioral control and its decomposed and awareness on intention to use e - money mobile in Indonesia, Computer Science 3(1), 39-50.

Khatimah, H., \& Halim, F. (2016b). The effect of attitude and its decomposed , subjective norm and it decomposed on intention to use E - money server in Indonesia, Computer Science $3(1), 21-32$.

Komiak, S. X., \& Benbasat, I. (2004). Understanding Customer Trust in Agent- Mediated Electronic Commerce, Web-Mediated Electronic Commerce, and Traditional Commerce. Information Technology and Management, 5(1/2), 181-207. https://doi.org/10.1023/B:ITEM.0000008081.55563.d4

Liébana-Cabanillas, F., de Luna, I. R., \& Montoro-Ríosa, F. (2017). Intention to use new mobile payment systems: A comparative analysis of SMS and NFC payments. Economic $\begin{array}{lll}\text { Research-Ekonomska } & \text { Istrazivanja, } & \text { 89(1), }\end{array}$ https://doi.org/10.1080/1331677X.2017.1305784

Mayer,R.C., Davis, J.H., Schoorman, F.D., (1995). An integrated model of organizational trust. Academy of Management Review, 30 (3) : 709-734

Mcknight, D. H., Choudhury, V., Kacmar, C., Mcknight, D. H., Choudhury, V., \& Kacmar, C. (2002). Developing and Validating Trust Measures for e-Commerce: An Integrative Typology. Information System Research, 13(3), 334-359. https://doi.org/10.1287/isre.13.3.334.81

Pamungkas, (2018). Pengaruh Kepercayaan, Kegunaan Dan Kemudahan Terhadap Minat Menggunakan Mobile Money T-Cash Studi Pada Mahasiswa Jurusan Perbankan Syariah Iain Surakarta, Skripsi,Institut Agama Islam Negeri Surakarta

Pavlou, P. A. (2001). Integrating Trust in Electronic Commerce with the Technology Acceptance Model : Model Development and Validation. AIS Electronic Library. Retrieved from http://aisel.aisnet.org/amcis2001

Pratama dan Suputra (2019). " Pengaruh Persepsi Manfaat, Persepsi Kemudahan Penggunaan, dan Tingkat Kepercayaan Pada Minat Menggunakan Uang Elektronik" Vol.27.2.Mei (2019): 927 - 953, E-Jurnal Akuntansi Universitas Udayana

Romadloniyah A.L Dan Prayitno D.H, 2014, Pengaruh Persepsi Kemudahan Penggunaan, Persepsi Daya Guna, Persepsi Kepercayaan, Dan Persepsi Manfaat Terhadap Minat Nasabah Dalam Menggunaan E-Money Pada Bank Bri Lamongan, Jurnal Penelitian Ekonomi Dan Akuntansi, Volume III No. 2

Ruiz et.al (2010). A comparative study of mobile messaging services acceptance to participate in television programmes. Journal of Service Management, 21(1), 69-102. https://doi.org/10.1108/09564231011025128

Schiffman, L., \& Kanuk, L. (2010). Consumer Behavior (10th ed.). USA: Pearson.

Sidharta I dan Sidh R (2014). Pengukuran Persepsi Manfaat Dan Persepsi Kemudahan Terhadap Sikap Serta Dampaknya Atas Penggunaan Ulang Online Shopphing Pada E-Commerce, Jurnal Computech \& Bisnis, Vol.8,No.2 pp, 92-100 
Sumerta,I.K., \&Wardana,I.M (2018), Analysis Of Intention To Use Electronic Money In Denpasar City TAM Approach, Archives Of Bussines Research, 6(10), 86-103

Teng, P. K., Ling, T. J., \& Seng, K. W. K. (2018). Understanding customer Intention to Use Mobile Payment Services in Nanjing, China. International Journal of Community Development and Management Studies, 2, 1-12.

Thompson, R. L., Higgins, C. A., Howell, J. M., Thompson, B. R. L., Higgins, C. A., Na, C., \& Howell, J. M. (1991). Personal Computing : Toward a Conceptual Model of Utilization1, 15(1), 125-143.

Ting, H., Yacob, Y., Liew, L., \& Lau, W. M. (2016). Intention to Use Mobile Payment System: A Case of Developing Market by Ethnicity. Procedia - Social and Behavioral Sciences, 224 pp 368-375. https://doi.org/10.1016/j.sbspro.2016.05.390

Venkatesh, V., Morris, M. G., Davis, G. B., \& Davis, F. D. (2003). User Acceptance of Information Technology : Toward a Unified View. MISQuarterly, 27(3), 425-478.

W. Stewart, D., Pavlou, P., \& Ward, S. (2002). Media Influences on Marketing Communications

Wibowo dkk (2015). Pengaruh Persepsi Manfaat, Persepsi Kemudahan, Fitur layanan \& Kepercayaan Terhadap Minat Menggunakan E-Money card (Studi pada pengguna jasa commuter line di Jakarta. JRMSI. Jurnal Riset Manajemen Sains Indonesia Vol. 6. No.1 pp: :440-456. 
